\title{
WILEY
}

\section{CHATHAM HOUSE}

The Expansion of Europe. by Ramsay Muir

Review by: H. E. Egerton

Journal of the British Institute of International Affairs, Vol. 1, No. 4 (Jul., 1922), pp. 126127

Published by: Wiley on behalf of the Royal Institute of International Affairs

Stable URL: http://www.jstor.org/stable/3014685

Accessed: 14/06/2014 05:48

Your use of the JSTOR archive indicates your acceptance of the Terms \& Conditions of Use, available at

http://www.jstor.org/page/info/about/policies/terms.jsp

JSTOR is a not-for-profit service that helps scholars, researchers, and students discover, use, and build upon a wide range of content in a trusted digital archive. We use information technology and tools to increase productivity and facilitate new forms of scholarship. For more information about JSTOR, please contact support@ jstor.org. 
No book of this magnitude could expect to be altogether free from blemishes or to mention every incident of importance. Section 559 on the American attitude towards loans to belligerent Governments should certainly have mentioned the Anglo-French loan of $£ 100,000,000$ in 1915. The issue of this loan in the United States was at variance with the line taken by the American Government in the earlier part of the war, and Professor Garner indicates the early American attitude somewhat fully. Similarly section 119 on the requisitioning of the Dutch merchant vessels in March 1918 by Great Britain and the United States ought to have included a reference to the memorandum contained in Lord Balfour's note of April 25th, 1918, wherein he set out exhaustively all the authorities in favour of the Allied action. It is a far more convincing reply to the Dutch protest than the American note, which merely asserted that the legal right of the United States was too well-founded to require the citation of precedent and authority. It was published in Parliamentary Papers, Misc. No. 11, 1918, and 111 State Papers, p. 522.

There are several little points which should be put right when opportunity serves; such as King Alexander, the late King of Greece, being the brother of King Constantine. Many little slips, too, are made in the names of men and ships mentioned in the book which are familiar to readers on this side of the Atlantic.

The work is so valuable and contains so much information that it is to be hoped that it will attain the circulation it deserves. Those who believe in the future of international law will certainly wish to have access to it. One can only add that it is a misfortune that the price at which the book has been issued, $£ 3128$. for the two volumes, should be so high. When the book reaches its second edition we shall look for a substantial reduction in the cost.

The Expansion of Europe. By Ramsay Muir. 3rd ed. (Constable \& Co., London. 1922. 12s. net.)

Tue dispassionate observer hardly knows whether to welcome or to deplore the fact that Mr. Ramsay Muir has transferred his energies from teaching history at a University to the, perhaps, more difficult task of strengthening the intellectual foundations of one of the great political parties. Assuredly, if The Expansion of Europe represents the views held by that party on imperial and foreign policy, no moderate man will complain of it on this ground. Of this masterly volume we may literally say, vires acquirit eundo, since the successive editions, which have added to its length, have added still more to its value and importance. What strikes especially the reader, who has had occasion to cover the same ground, is the manner in which the author, when dealing with the past history, seizes upon the salient facts, and obtains brevity without lapsing into vagueness or loose generalisation. In his historical judgments he always shows complete independence of thought and detachment from party prejudices. Here and there one may not agree with him. Thus we are told that the Monroe Message was "in effect a declaration of support for Britain " and "an alliance for the defence of freedom." But, whatever may have been Jefferson's views in his old age, the American Secretary of State, John Quincy Adams, who was mainly responsible for the Message, was obsessed with the view that Great Britain was hankering after Cuba; and the Message 
was intended as a warning to Europe as a whole, including Great Britain, that, though the United States might tolerate the status quo, any further encroachments would be resisted, and Canning recognised that " the avowed pretension of the United States to put themselves at the head of the Confederacy of all the Americas . . . is not a pretension identified with our interests, or one that we can countenance as tolerable."

Inspired with confidence by Mr. Ramsay Muir's treatment of the past, one turns with interest to his views regarding the Versailles Treaty. In passing we note his weighty judgment on "self-determination": "There never was a more mischievous phrase . . . for it obscures the fact that no man, and no nation, either can, or may, singly determine his own fate, without regard to others, and that 'ourselves alone' is the most destructive and sterile of creeds; it disregards the fact that, even if it were possible, 'self-determination' postulates a self, and it is only by slow and painful process that any body of people acquires a 'self,' obtains that self-conscious unity and homogeneity which selfhood implies-becomes, in short, a nation."

Turning to the character of the settlement, we find that the two main objections taken to it are the usurpation by the Supreme Council of powers that should belong to the League of Nations, and the language of Article 10 of the Covenant of the League, which practically guarantees the territorial integrity of all the Member states. It is obviously futile to claim absolute finality for any settlement, however reasonable at the time of its making. The Assembly of the League, however, has fortunately the power to amend its own Constitution. The other objection approaches more thorny ground. With the withdrawal of the United States and with Germany and Russia conspicuous by their absence, is the League of Nations, as at present constituted, strong enough to undertake the burden of acting as a World Tribunal? But the moral of this volume is that the affairs of Europe have now become conterminous with those of the world. It may be delicately hinted that what is wrong with Europe arises not so much from the action of individual statesmen as from the fact that the old hatreds and suspicions still prevail. France honestly believes that there has been no change of heart in Germany, and that it is therefore still necessary to hold her down by force; whilst, with such a temper prevailing, is Germany likely to mend her ways? These, however, are high themes into which the present writer is not competent to enter; he merely hazards the opinion that in this judgment, if anywhere, Mr. Ramsay Muir hardly shows his usual tolerance and appreciation of practical difficulties.

The author is seen at his best in his description of the British Commonwealth of Nations. It " is all quite illogical; but is illogical just because it is not mechanical but organic; it grows like a plant, adapting itself continually to new needs; it is not manufactured to a pattern like a machine. . . . It has the variety and unexpectedness of life." In short, whether for its form or its substance, the book is one which it is impossible to praise too warmly.

H. E. Egerton. 